\title{
Preparation of Anodized Titanium Plates with Photocatalytic Activity
}

\author{
Seishiro ITO*, Jun KURAKI*, Hiroaki TADA** and Mitsunobu IWASAKI*
}

光触媒活性を有するチタン陽極酸化皮膜材の作製

伊藤征司郎*，倉木 淳*，多田弘明**，岩崎光伸*

Key Words : Photocatalyst, Titanium, Anodized Film

\section{Introduction}

Titanium oxide films formed by heating or anodic oxidation on the surface of metallic titanium plates interfere with visible light, and act as photocatalysts ${ }^{1}$. However, these oxide films lack durability because of their insufficient thickness which is less than $1 \mu \mathrm{m}$. Ito et al. previously developed a method of producing porous anodic oxide films that are more than $1 \mu \mathrm{m}$ thick $^{2}$. This method consists of anodic oxidation of titanium plates under high voltage in a mixture of $\mathrm{H}_{2} \mathrm{SO}_{4}, \mathrm{H}_{3} \mathrm{PO}_{4}$, and $\mathrm{H}_{2} \mathrm{O}_{2}$. Although these thick, gray films contain low valent titanium oxides and have sufficient durability ${ }^{3)}$, they are photocatalytically inactive. There is a possibility that the low valent titanium oxides cause the photocatalytic inactivity.

This study has sought to sustain photocatalytic activity with the thick, anodized films by removing the low valent titanium oxides.

\section{Experimental}

Commercially pure titanium (JIS H 4600 , class 1) was used as a titanium substrate $(30 \times 50 \times 0.4 \mathrm{~mm}$ $[\mathrm{W} \times \mathrm{L} \times \mathrm{T}])$. For the first anodic oxidation, the voltage was raised from 0 to $200 \mathrm{~V}$ at a constant current density of DC $300 \mathrm{~A} / \mathrm{m}^{2}$ in a solution of $1.5-\mathrm{M} \mathrm{H}_{2} \mathrm{SO}_{4}$, $0.3-\mathrm{M} \mathrm{H}_{3} \mathrm{PO}_{4}$, and 0.3- $\mathrm{M} \mathrm{H}_{2} \mathrm{O}_{2}$, and then was kept at this voltage (which was a constant voltage). It took 10 minutes to raise the voltage to $200 \mathrm{~V}$, and the total anodizing time was 30 minutes. The bath temperature was maintained at $303 \mathrm{~K}$. The titanium substrate was employed as a cathode as well as an anode, and the distance between electrodes was $5 \mathrm{~cm}$. The thickness of the anodic oxide film obtained was $5.5 \mu \mathrm{m}$. For the second anodic oxidation, the voltage was raised to 150

* Fac. of Sci. and Eng., Kinki Univ. (3-4-1, Kowakae, Higashi-Osaka-shi, Osaka 577-8502) 近畿大学 理工学部

**Environmental Sci. Research Institute, Kinki Univ. (3-4 -1, Kowakae, Higashi-Osaka-shi, Osaka 577-8502) 近畿大学 環境科学研究所
$\mathrm{V}$ at a constant current density of DC $300 \mathrm{~A} / \mathrm{m}^{2}$ for 2 minutes in a mixture of $\mathrm{NH}_{4} \mathrm{HF}_{2}$ and $0.3-\mathrm{M} \mathrm{H}_{2} \mathrm{O}_{2}$, and was maintained at $150 \mathrm{~V}$. Total anodizing time was varied in the range of 5 to 15 minutes. The cathode material and the distance between electrodes were identical to those in the first anodizing process.

Photocatalytic activity was evaluated in terms of the photooxidation decomposition reaction of $\mathrm{CH}_{3} \mathrm{CHO}$ gas. A xenon lamp (Wacom HX-500) was used as a light source. The irradiation area and the strength of the light were set at $15 \mathrm{~cm}^{2}$ and $28 \mathrm{~W} / \mathrm{m}^{2}$ (at $320-400 \mathrm{~nm}$ in wavelength), respectively. The volume of the reaction vessel was fixed at $640 \mathrm{~mL}$. Acetaldehyde was quantitatively measured using a gas chromatograph (Shimadzu GC-9 A).

\section{Results and Discussion}

\section{First anodizing}

The diffraction peaks due solely to anatase and metallic titanium were seen in XRD patterns of the first anodized films. However, the films contain lower valent titanium oxides such as $\mathrm{TiO}$ and $\mathrm{Ti}_{2} \mathrm{O}_{3}$, excepting $\mathrm{TiO}_{2}{ }^{3)}$. A deep coloration (blue or black) of the films can be attributed to the lower valent titanium ions included in the films ${ }^{4}$.

\section{Second anodizing}

The SEM photographs and XRD patterns of the samples obtained after re-anodization of the first anodized films were quite similar to those of the original samples. The depth profiles measured by a glow discharge-optical emission spectrometer (GDOES) showed the presence of $\mathrm{P}$ and $\mathrm{S}$, which derive from $\mathrm{PO}_{4}{ }^{3-}$ and $\mathrm{SO}_{4}{ }^{2-}$, respectively, in addition to $\mathrm{Ti}$ and $\mathrm{O}$ in both the first and second anodized films. Fluorine was also detected by XPS, and the $F_{1 s}$ peak intensity remained after etching the surface for 10 minutes with $\mathrm{Ar}^{+}$ions. After the 2 nd anodic oxidation, the film color became whiter, and its $\mathrm{L}^{*}$ value (an indicator of lightness) increased from 54 to 57 69 ; the latter value depends on the electrolytic condi- 


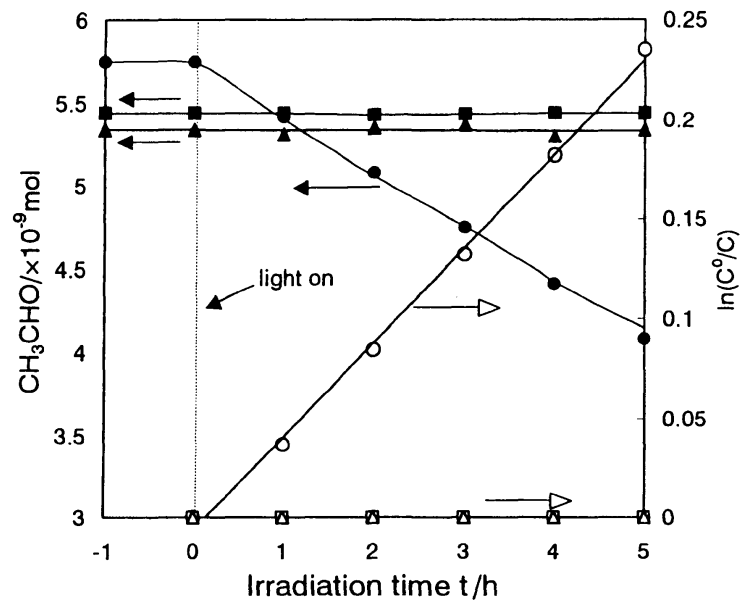

Fig. 1 The variation of the $\mathrm{CH}_{3} \mathrm{CHO}$ concentration with time and plots of $\ln \left(\mathrm{C}^{0} / \mathrm{C}\right)$ vs. time for titanium substrate, first and second anodized films.

$\square$ : titanium substrate

$\Delta \triangle$ : first anodized film

0 : second anodized film

tions. The thickness of the second anodized film decreased by about $1 \mu \mathrm{m}$ as compared to that of the first.

\section{Photocatalytic activity}

The photocatalytic activities are shown in Fig. 1. The second anodized film was prepared in a solution of $0.05-\mathrm{M} \mathrm{NH}_{4} \mathrm{HF}_{2}$ and $0.3-\mathrm{M} \mathrm{H}_{2} \mathrm{O}_{2}$ at a $303 \mathrm{~K}$ bath for 5 minutes. The photocatalytic activity of the titanium substrate and the first anodized film are negligible, whereas the second anodized film is photocatalytically active under UV/vis light. Moreover, plotting $\ln \left(\mathrm{C}^{0} / \mathrm{C}\right)$ vs time $(\mathrm{t})$ revealed a straight line, where $\mathrm{C}^{\circ}$ and $\mathrm{C}$ are the concentration of acetaldehyde at $t=0$ and $t=t$, respectively. This result indicates that the photocatalytic reaction follows the first order rate equation ${ }^{5}$. The apparent rate constant $(\mathrm{k})$ was calculated from the slope of the straight line as $0.047 \mathrm{~h}^{-1}$. Table 1 summarizes $\mathrm{k}$ for the second anodized films produced under different conditions. The value of $k$ increases with increasing lightness $\left(\mathrm{L}^{*}\right)$ for the second set of anodized films.

Generation of photocatalytic activity by the second anodic oxidation is clearly evident. Since the low valent titanium oxides exist in the first anodized films that are predominantly composed of anatase-type crystal as described above ${ }^{3)}$, the films have no photocatalytic activity. Some impurities in $\mathrm{TiO}_{2}$ usually impede photocatalytic activity and decrease 0 quantum efficiency ${ }^{6,7)}$. It is likely that $\mathrm{TiO}$ and $\mathrm{Ti}_{2} \mathrm{O}_{3}$ produced during the first anodic oxidation serve as the recombination centers of the photogenerated charge
Table 1 Apparent rate constant (k) and lightness $\left(\mathrm{L}^{*}\right)$ of second anodized films.

\begin{tabular}{c|c|c|c|c}
\hline $\begin{array}{c}\text { Bath } \\
\text { temperature } / \mathrm{K}\end{array}$ & $\mathrm{NH}_{4} \mathrm{HF}_{2} / \mathrm{M}$ & $\begin{array}{c}\text { Anodic } \\
\text { oxidation } \\
\text { time } / \mathrm{min}\end{array}$ & $\mathrm{k} / \mathrm{h}^{-1}$ & $\mathrm{~L}^{*}$ \\
\hline & 0.01 & 5 & $\simeq 0$ & 56 \\
293 & 0.01 & 10 & $\simeq 0$ & 57 \\
& 0.01 & 15 & $\simeq 0$ & 59 \\
& 0.05 & 5 & 0.018 & 59 \\
& 0.05 & 10 & 0.023 & 60 \\
& 0.05 & 15 & 0.026 & 61 \\
& 0.1 & 5 & 0.027 & 61 \\
\hline \multirow{3}{*}{303} & 0.01 & 5 & 0.025 & 57 \\
& 0.01 & 10 & 0.024 & 59 \\
& 0.01 & 15 & 0.027 & 60 \\
& 0.05 & 5 & 0.047 & 62 \\
& 0.05 & 10 & 0.054 & 69 \\
& 0.1 & 5 & 0.054 & 67 \\
\hline \multirow{5}{*}{313} & 0.01 & 5 & 0.019 & 56 \\
& 0.01 & 10 & 0.022 & 60 \\
& 0.01 & 15 & 0.025 & 60 \\
& 0.05 & 5 & 0.051 & 64 \\
& 0.05 & 10 & 0.052 & 69 \\
\hline
\end{tabular}

carriers to reduce the photocatalytic activity. Since most of these lower valent titanium oxides were removed during the second anodic oxidation, the resultant films consisting mainly of anatase $\mathrm{TiO}_{2}$ exhibit photocatalytic activity. It follows that a positive correlation between the photocatalytic activity and the $L^{*}$ value exists.

\section{Conclusion}

A porous anodic oxide film of about $5.5 \mathrm{~mm}$ in thickness was anodized on a titanium substrate at a voltage of $200 \mathrm{~V}$ in a mixture of $\mathrm{H}_{2} \mathrm{SO}_{4}, \mathrm{H}_{3} \mathrm{PO}_{4}$, and $\mathrm{H}_{2} \mathrm{O}_{2}$ (the first anodized film). The film was again anodized in a solution of $\mathrm{NH}_{4} \mathrm{HF}_{2}$ and $\mathrm{H}_{2} \mathrm{O}_{2}$ (the second anodized film). The first anodized film showed no photodecomposition reaction for $\mathrm{CH}_{3} \mathrm{CHO}$ gas, although the film consisted predominantly of anatase $\left(\mathrm{TiO}_{2}\right)$. The second anodized film exhibited a higher degree of lightness with ample photocatalytic activity.

(Received August 20, 1999 ; Accepted October 26, 1999)

\section{References}

1) A. Fujishima, K. Kohayakawa ; J. Electrochem. Soc., 122, 1487 (1975)

2) S. Ito, T. Haneda, K. Koizuka ; Zairyo Gijutsu, 10, 152 (1992)

3) T. Shibata, Y.-C. Zhu ; Denki Kagaku, 61, 853 (1993)

4 ) S. Ito, Y. Uozumi, T. Onaka, T. Tsubaki ; J. Jpn. Inst. Light Metals, 39, 361 (1989)

5 ) S. Ito, T. Deguchi, K. Imai, M. Iwasaki, H. Tada ; Electrochem. Solid-State Lett., 2, 440 (1999)

6) M. R. Hoffmann, S. T. Martin, W. Choi, D. W. Bahnemann; Chem. Rev., 95, 69 (1995)

7 ) M. Anpo, M. Takeuchi, S. Kishiguchi, H. Yamashita ; $J$. Surface Sci. Soc. Jpn., 20, 60 (1999) 